\title{
Effect of some selected insecticides on the activity of invertase at different stages of pentatomid bug, Cyclopelta siccifolia W.
}

\author{
A. Naveed*, G.Y. Dayananda and B.B. Hosetti \\ Department of Applied Zoology, Biosciences complex, Kuvempu University Shankaraghatta - 577451 (Karnataka), INDIA \\ *Anjuman Arts,Science and Commerce College, Bhatkal, Uttarkannada Dist. (Karnataka), INDIA \\ *Corresponding author. E-mail: na_veed2000@yahoo.com
}

\begin{abstract}
The invertase enzyme which has been reported to occur in the digestive tract of several insects is believed to be an important enzyme for digestion and utilization of sucrose by insects. In the present investigation the effect of different insecticides such as Endosulfan, Monocrotophos, Methomyl, Phosphomidon and Carbaryl on invertase activity has been carried out at different stages of Pentatomid bug Cyclopelta siccifolia W. with lethal concentrations of respective insecticides. The data revealed that maximum decrease in Invertase activity was detected with (45\%) at 24 hours. In case of II instar nymphs the least activity was observed with Carbaryl and it was $-75.20 \%$ at 24 hours. In IV instar nymphs endosulfan showed its supremacy by reducing the activity by $-8.5 \%$ in comparison with control. The overall results revealed that the activity of invertase varies with different insecticide treatments and it has been concluded that least activity was recorded with Carbaryl at II instar stage compared to other insecticides.
\end{abstract}

Keywords: Petatomid bug, Cyclopelta siccifolia, Invertase, Insecticides

\section{INTRODUCTION}

The Pentatomid bug Cyclopelta siccifolia W. is a major pest on economically important tree Pongamia pinnata. The insect comprises 7 instar nymphal stages, all stages are phytophagus, mainly depending upon sucking the plant sap. The digestive enzymes in insects are commonly found in the salivary secretions and regions of digestive tract have been reviewed (House, 1965). The digestive enzymes in insects generally adapted to the specific diet on which the species feed (Wigglesworth, 1963). The invertase enzyme has been reported to occur in digestive tract of several insects is believed to be important for digestion and utilization of sucrose by insects. In the present investigation the impact of different insecticides on the digestive enzyme invertase has been studied.

\section{MATERIALS AND METHODS}

To conduct bio-assay and effect of different insecticides on the activity of Invertase in adults and different selected instars of Cyclopelta siccifolia $\mathrm{W}$, the insects were exposed to lethal concentrations of different insecticides such as Endosulfan, Monocrotophos, Carbaryl, Methomyl and Phosphomidon (Table 1). The insects were collected from Pongamia pinnata tree from near by Applied Zoology Department, Kuvempu University, Bhadra Reservoir Project area. The treated insects were washed thoroughly, legs, head and wings were removed and grained in chilled glass tissue grinder along with $0.7 \%$
$\mathrm{NaCl}$. The homogenate was centrifuged for $5000 \mathrm{rpm}$ for $30 \mathrm{~min}$. The aliquot of the supernatant was filtered through glass wool to remove fatty material. The enzyme assay was carried out according to Ishaaya and Swiriski (1970). The optimum $\mathrm{pH}$, optimum temperature, substrate concentration and incubation time were determined earlier and the $\mathrm{pH}$ was 5.6 , optimum temperature $45^{\circ} \mathrm{C}$, substrate concentration $3 \%$ and incubation time $60 \mathrm{~min}$. For Control, insects were collected from the plants and acclimatized to the lab conditions for 24 hours and enzyme essay carried out by the above said method.

Table 1. Lethal concentrations of different insecticides exposed to Cyclopelta siccifolia.

\begin{tabular}{lcccccc}
\hline \multirow{2}{*}{ Insecticides } & \multicolumn{2}{c}{ Adult } & \multicolumn{2}{c}{ II Instar } & \multicolumn{2}{c}{ IV Instar } \\
\cline { 2 - 7 } & 24 & 48 & 24 & 48 & 24 & 48 \\
& hrs & hrs & hrs & hrs & hrs & hrs \\
\hline Methomyl & 2.65 & 2.45 & 0.51 & 0.31 & 0.51 & 0.62 \\
Endosulfan & 5.0 & 4.2 & 0.66 & 0.62 & 0.66 & 1.81 \\
Monocrotophos & 20.0 & 15.65 & 2.0 & 2.65 & 2.0 & 2.65 \\
Carbaryl & 43.0 & 37.5 & 3.35 & 3.0 & 4.2 & 3.95 \\
Phosphomidon & 66.0 & 61.5 & 25 & 21.0 & 35.0 & 30.5 \\
\hline
\end{tabular}

* All the concentrations are in ppm

\section{RESULTS AND DISCUSSION}

The insects treated with lethal concentrations of different insecticides revealed varied results with varied duration. 
In adults the activity of invertase decreased (-45.53\%) with Monocrotophos followed by remaining insecticides such as Methomyl (-43.34\%), Carbaryl (-42.60\%), Endosulfan (-41.53\%) and Phosphomidon (-40.24\%) respectively (Table 1). In II instar nymphs rapid decrease in the activity of invertase was witnessed with Carbaryl and it was $-75.20 \%$ at 24 hours. The other insecticides ranked the consecutive positions. In IV instar nymphs the supremacy in invertase enzyme inhibition was evidenced by Endosulfan (-8.5\%). The activity of invertase in the IV instar was least affected by the impact of insecticides, it was Monocrotophos (-3.90\%), Methomyl (-3.51\%), Phosphomidon (-3.1\%) and Carbaryl $(-1.10 \%)$ respectively. In VI instar nymphs decrease in invertase activity was maximum with Methomyl and it was $-34.30 \%$. The other insecticides such as Endosulfan, Monocrotophs, Phosphomidon and Carbaryl showed that the inhibition rate was lower. At 48 hours least activity was observed with Methomyl in adults, II and VI instar nymphs. In case of IV instar nymphs the decrease in the activity of invertase was higher with Endosulfan (Table. 1).

Kuruppasamy et al. (2001) showed that the reduction in enzyme synthesis was due to the direct effect of toxicants on the synthesis. In the present investigation the activity of digestive enzyme invertase was used as parameter for studying the effect of insecticides. It has been observed that at 24 hours least activity of invertase was observed with Carbaryl in II instar nymphs. At 48 hours, the activity was observed to be highly declined in presence of Methomyl in II instar. The invertase activity was minimum in presence of insecticides in II instar stage. These observations are in conformity with findings of Vatsala and Choklingum (1986) who observed the effect of insecticides resulting into the inhibition of digestive enzymes in Spodoptera litura and same type of observation was also made by Lomte and Patil (1989) on army worm caterpillar Mythimia separata. Similar observation has also been reported for feeding insect pest Aspongopus janus, Chrysocoris stollii and Deysdescus cingulatus (Rekha et al.,2000).

Table 2. Effect of different insecticides on the activity of invertase in adult, II instar, instars and VI instars of pentatomid bug $C$. siccifolia $\mathrm{W}$.

\begin{tabular}{ccccccccc}
\hline Insecticides & \multicolumn{2}{c}{ II Instar } & \multicolumn{2}{c}{ IV Instar } & \multicolumn{2}{c}{ VI Instar } & \multicolumn{2}{c}{ Adult } \\
\hline & 24 hours & 48 hours & 24 hours & 48 hours & 24 hours & 48 hours & 24 hours & 48 hours \\
\hline \multirow{2}{*}{ Endosulfan } & $19.98 \pm 0.06$ & $10.83 \pm 0.2$ & $23.40 \pm 0.62$ & $16.40 \pm 0.16$ & $25.80 \pm 0.19$ & $16.40 \pm .0 .16$ & $23.97 \pm 0.02$ & $15.80 \pm 0.002$ \\
& $(-47.2 \%)$ & $(-58.82 \%)$ & $(-8.5 \%)$ & $(-53.37 \%)$ & $(-32.2 \%)$ & $(-32.37 \%)$ & $(-41.23 \%)$ & $(-56 \pm 1 \%)$ \\
& $18.35 \pm 0.35$ & $12.40 \pm 0.14$ & $24.66 \pm 0.5$ & $15.5 \pm 0.1$ & $26.8 \pm 0.09$ & $15.1 \pm 0.05$ & $22.33 \pm 0.36$ & $16.11 \pm 0.05$ \\
Monocrotophos & $(-51.71 \%)$ & $(-52.85 \%)$ & $(-3.90 \%)$ & $(-46.92 \%)$ & $(-29.6 \%)$ & $(-56.8 \%)$ & $(-45.53 \%)$ & $(-58.4 \%)$ \\
& $19.10 \pm 0.03$ & $10.20 \pm 0.007$ & $24.7 \pm 0.15$ & $16.06 \pm 0.05$ & $25.03 \pm 0.27$ & $15.1 \pm 0.03$ & $23.23 \pm 0.36$ & $14.96 \pm 0.05$ \\
Methomyl & $(-49.68 \%)$ & $(-61.21 \%)$ & $(-3.51 \%)$ & $(-51.57 \%)$ & $(-34.30 \%)$ & $(-56.8 \%)$ & $(-43.23 \%)$ & $(-58.4 \%)$ \\
& $18.33 \pm 0.35$ & $12.40 \pm 0.14$ & $24.8 \pm 0.36$ & $16.60 \pm 0.22$ & $27.46 \pm 0.1$ & $17.03 \pm 0.05$ & $24.5 \pm 0.21$ & $17.9 \pm 0.35$ \\
Phosphomidon & $(-51.71 \%)$ & $(-52.85 \%)$ & $(-3.1 \%)$ & $(-49.7 \%)$ & $(-27.9 \%)$ & $(-51.3 \%)$ & $(-40.24 \%)$ & $(-50.2 \%)$ \\
& $18.58 \pm 0.21$ & $13.0 \pm 0.03$ & $24.86 \pm 0.36$ & $16.60 \pm 0.22$ & $27.53 \pm 0.64$ & $17.03 \pm 0.05$ & $23.53 \pm 0.40$ & $16.81 \pm 0.18$ \\
Carbaryl & $(-75.20 \%)$ & $(-50.57 \%)$ & $(-1.01 \%)$ & $(-49.83 \%)$ & $(-27.82 \%)$ & $(-51.3 \%)$ & $(-42.60 \%)$ & $(-53.30 \%)$ \\
Control & $37.96 \pm 0.20$ & $26.30 \pm 0.14$ & $25.6 \pm 0.51$ & $33.03 \pm 0.05$ & $38.16 \pm 0.05$ & $35.0 \pm 1.6$ & $41.0 \pm 0.04$ & $36.0 \pm 0.007$ \\
\hline
\end{tabular}

\pm indicates standard error, each value is the mean of 6 replications; enzyme activity for Invertase expressed in terms of $\mu \mathrm{g}$ glucose $/ \mathrm{ml} /$ mg tissue/hour

\section{REFERENCES}

House, H.L. (1965). Digestion. In: The physiology of insecta. Vol.3, Rockstein, M (Eds.,) Academic Press, NewYork. Pp. $815-858$

Ishaaya, I. and Swirski, E. (1970). Invertase and amylase activity in the armored scales Chrysomphalus aonidum and Aonidiella aurantii. J. Insect. Physiol., 16: 1599-1606.

Kurappasamy, R.C., Ecanthezhiyan and Parasarthi, K. (2001). Inhibitory effects of Annona squamota (Annonaceae) on the digestive enzymes of Pheropsophus hilaris (fabr.) (Coleoptera: Carabidae). Environmental and Ecology, 19:584587.
Lomte, V.S. and Patil. (1989). Effects of some common pesticides on the digestive enzymes of armyworm Mythimia separata. Indian J. Inv. Zool and Aqua. Biol., 1(2): 58-67.

Rekha, S., Misahuddin and Ehteshamudin, S. (2000). Effect of phosphomidon on the alkaline phophotase activity in the haemolymph and sap feeding insect pest Aspongopus janus, Chrysocoris stollii and Deysdescus cingulatus. Environment and Ecology, 18:323-325.

Vatsala, E. and Chocklingam. (1986). Effects of insecticides on the inhibition of digestive enzymes in Spodotera litura. Proc. Nat. Insect. Physiol.Ecol and Behv., 50: 25-29.

Wigglesworth, V.B. (1963). The principles of insect physiology, Chappman and Hall, London. 